\title{
Separation and Preconcentration of Gallium(III), Indium(III), and Thallium(III) Using New Hydrazone-modified Resin
}

\author{
Mohammad M. Hassanien, * Ibrahim M. Kenawy,** Adel M. El-Menshawy,** \\ and Ahmed A. EL-ASMY**ं \\ *Chemistry Department, Industrial Education College, Beni-Suef University, Egypt \\ **Chemistry Department, Faculty of Science, Mansoura University, Mansoura, Egypt
}

$\mathrm{Ga}(\mathrm{III}), \mathrm{In}(\mathrm{III})$ and $\mathrm{Tl}(\mathrm{III})$ ions in the presence of different sulfate salts have been successfully separated using 1-(3,4dihydroxybenzaldehyde)-2-acetylpyridiniumchloride hydrazone (DAPCH) loaded on Duolite C20 in batch and column modes. The obtained modified resin as well as the metal complexes was characterized by elemental analysis and infrared spectra. The extraction isotherms were determined at different $\mathrm{pH}$ values. Ga(III) and $\mathrm{In}(\mathrm{III})$ are sorbed from aqueous solution at $\mathrm{pH} 2.5-3.0$ while $\mathrm{Tl}(\mathrm{III})$ is sorbed at 2.0. The stripping of the adsorbed ions can be carried out using different concentrations of $\mathrm{HCl}$ as eluent. The saturation sorption capacities of $\mathrm{Ga}(\mathrm{III}), \mathrm{In}(\mathrm{III})$ and $\mathrm{Tl}(\mathrm{III})$ were $0.82,0.96$ and 0.44 mmol g-1, where the preconcentration factors are 150, 150 and 100, respectively. The metal(III):Duolite C20-DAPCH ratio was $1: 2$ for $\mathrm{Tl}(\mathrm{III})$ and $1: 1$ for $\mathrm{In}(\mathrm{III})$ and $\mathrm{Ga}(\mathrm{III})$. The loaded resin can be regenerated for at least 50 cycles. The utility of the modified resin was tested in aqueous samples and the results show an RSD value of $<5 \%$ reflecting their accuracy and reproducibility.

(Received March 30, 2007; Accepted June 4, 2007; Published December 10, 2007)

\section{Introduction}

$\mathrm{Ga}(\mathrm{III}), \mathrm{In}(\mathrm{III})$ and $\mathrm{Tl}(\mathrm{III})$ are widely distributed in the earth's crust and water system and present toxic manifestations when ingested by living systems. ${ }^{1}$ These elements find several uses in industry. Gallium is used in electronic devices, especially in the manufacture of gallium arsenide laser diodes, semiconductors and superconductors. It has applications in aerospace, shipbuilding, cryogenics, medicine, atomic reactors and electronic industry. Thallium and its compounds are used in photocells, infrared detectors, low temperature switches and special glasses. Their concentrations need control, especially in nuclear reactors. Tooth decay, pain in joints and bones, nervous and gastrointestinal disorders, heart pain and general disability are the effects of excessive exposure or ingestion of $\mathrm{Ga}(\mathrm{III})$ or $\mathrm{In}(\mathrm{III})$. $\mathrm{Tl}(\mathrm{III})$ is a well-known poison and its action is cumulative. It causes polyneuritis, convulsion, coma and even death. ${ }^{1}$

Low concentrations of $\mathrm{Ga}(\mathrm{III}), \mathrm{In}(\mathrm{III})$ and $\mathrm{Tl}(\mathrm{III})$ are not easily detected and high levels of potentially interfering constituents preclude their direct determination. Various preconcentration tools are employed prior to their analysis..$^{2-20}$ Liquid-liquid extraction $^{2-5}$ is effective for separation and preconcentration of cations, including these metals. Several researchers have studied the fundamental extraction behavior ${ }^{6-14}$ and the mutual extractive separation ${ }^{15-20}$ of trivalent group 13 metal cations using many kinds of extractants. ${ }^{21-28}$ In spite of its versatility, multi-stage extraction procedures, disposal of large volumes of organic wastes and expensive treatment are the main problems.

Solid phase extraction (SPE) has major advantages over liquidliquid extraction, including the fast, simple, direct application in

$\dagger$ To whom correspondence should be addressed.

E-mail: aelasmy@yahoo.com micro level, no waste generation, low risk of contamination, and time- and cost-saving. Modified resins containing methylenediphosphonate, ${ }^{29}$ carboxymethylphosphonate, ${ }^{30}$ substituted malonamides, ${ }^{31}$ and substituted phenylphosphinic acid ${ }^{32}$ have been applied for the separation of $\mathrm{Ga}$ (III), In(III) and Tl(III). They face difficulty because of the difficulties of preparation and the lower sorption capacity; few were actually used. The aim of this work is to investigate the ability of the introduced modified resin for adsorption and elution of indium, gallium and thallium from sulfate samples. 1-(3,4-Dihydroxybenzaldehyde)2-acetylpyridiniumchloride hydrazone (DAPCH, 1-[2-oxo-2[(3,4-dihydroxyphenylmethylene)hydrazino]ethyl]pyridinium chloride) was selected from among the possible reagents due to the following advantages: i) hydrazone compounds have a strong ability to chelate metal ions; ii) it contains two adjacent $\mathrm{OH}$ groups in addition to the active groups in the hydrazone moiety, forming two five-membered rings that increase the stability; and iii) the quaternary ammonium ion moiety associates strongly with the $-\mathrm{SO}_{3}{ }^{-}$groups of Duolite $\mathrm{C} 20$, which was chosen as the base resin.

\section{Experimental}

\section{Reagents}

A stock solution of $\operatorname{In}(\mathrm{III})\left(1000 \mu \mathrm{g} \mathrm{ml}^{-1}\right)$ was prepared by dissolving $1 \mathrm{~g}$ of In (Aldrich) in $5 \mathrm{ml}$ concentrated nitric acid, the mixture was evaporated till dryness and then another $3 \mathrm{ml}$ were added and the volume was completed to 11 with bidistilled water. Here a $1000 \mu \mathrm{g} \mathrm{ml}^{-1}$ solution of $\mathrm{Ga}$ (III) was prepared by dissolving $1 \mathrm{~g}$ of $\mathrm{Ga}$ (Aldrich) in aqua regia $(3 \mathrm{ml} \mathrm{HCl}: 1 \mathrm{ml}$ $\mathrm{HNO}_{3}$ ) and the mixture was diluted to 11 of bidistilled water. They were standardized by titration with EDTA. All required concentrations were prepared by dilution. The stock solution of 


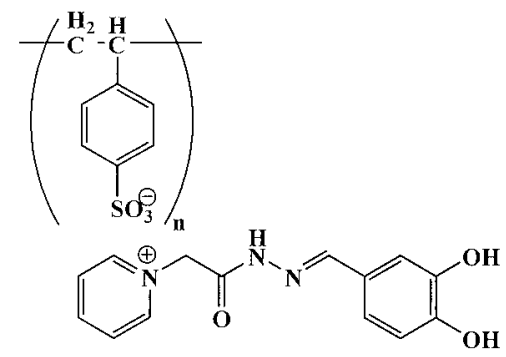

Scheme 1 Structure of DAPCH loaded on Duolite C20 resin.

$\mathrm{Tl}\left(1000 \mu \mathrm{g} \mathrm{ml}^{-1}\right)$ was prepared by dissolving $0.293 \mathrm{~g}$ of $\mathrm{TlCl}$ in $25 \mathrm{ml}$ of distilled water. Two drops of bromine water was added to oxidize $\mathrm{Tl}(\mathrm{I})$ to $\mathrm{Tl}(\mathrm{III})$; the mixture was warmed to remove excess bromine, cooled and diluted to 11 . Girard's reagent $P$ (GP), sodium chloride and 3,4-dihydroxybenzaldehyde were purchased from Aldrich, Duolite C20 from Rohm and Hass Co. Hydrochloric acid, sodium hydroxide and the other reagents were analytical grade (BDH Chemicals Ltd., Poole, England).

\section{Apparatus}

The IR spectra were measured as $\mathrm{KBr}$ disks on a Mattson 5000 FTIR spectrophotometer $\left(4000-400 \mathrm{~cm}^{-1}\right)$. The spectrophotometric measurements were performed on a Unicam UV-Vis UV2 spectrophotometer using a $1-\mathrm{cm}$ quartz cell. The $\mathrm{pH}$ values were measured using a glass electrode $\mathrm{pH}$-meter (Hanna Instruments, 8519, Italy) with an accuracy of \pm 0.01 .

Preparation of 1-(3,4-dihydroxybenzaldehyde)-2-acetylpyridiniumchloride hydrazone (DAPCH)

DAPCH was prepared by heating $5 \mathrm{~g}$ of GP with $3.7 \mathrm{~g} \mathrm{3,4-}$ dihydroxybenzaldehyde in $20 \mathrm{ml}$ absolute ethanol and five drops of glacial acetic acid under reflux on a water bath for $4 \mathrm{~h}$. The yellow precipitate thus formed is filtered off, recrystallized from ethanol and finally dried in a vacuum desiccator over anhydrous calcium chloride, m.p. $281-282^{\circ} \mathrm{C}$.

\section{Preparation of the modified resin (Duolite C20-DAPCH)}

In a round bottle flask, $1 \mathrm{~g}$ of the resin and $10 \mathrm{ml}$ portion of $10^{-3} \mathrm{~mol}^{-1} \mathrm{DAPCH}$ in bidistilled water are mixed and mechanically stirred for $10 \mathrm{~min}$ at $80^{\circ} \mathrm{C}$. The mother liquor is decantated, replaced by another $10 \mathrm{ml}$ of DAPCH solution and this process is repeated until saturation. To follow the progress of the reaction, one can remove $1 \mathrm{ml}$ of the mother liquor with buffer $\mathrm{pH} 10$ and measure the intensity of the produced yellow color at $365 \mathrm{~nm}$. The absorbance value is taken as a criterion for the complete loading process. The modified resin (Scheme 1) is then filtered off, rinsed several times with bidistilled water, dried and stored. The amount of DAPCH sorbed on Duolite C20 is $1.04 \mathrm{mmol} \mathrm{g}^{-1}$.

\section{Separation procedures}

Batch method. A sample solution $(100 \mathrm{ml})$ containing $50 \mu \mathrm{g}$ $\mathrm{ml}^{-1}$ of the studied metal ion was transferred to a $250-\mathrm{ml}$ stoppered glass bottle. After the $\mathrm{pH}$ was adjusted to the optimum value, $50 \mathrm{mg}$ of the modified resin was added. The mixture was shaken for $30 \mathrm{~min}$, filtered, washed with bidistilled water, and the sorbed metal ion was eluted with $5 \mathrm{ml}$ of the suitable concentration of $\mathrm{HCl}$. The metal ion was determined spectrophotometrically using xylenol orange. ${ }^{33}$

Column method. Duolite C20-DAPCH (0.5 g) was firstly swollen for $24 \mathrm{~h}$, then packed in a glass column $(6 \times 40 \mathrm{~mm})$, treated with $1 \mathrm{~mol} \mathrm{l}^{-1} \mathrm{HCl}(20 \mathrm{ml})$ at the optimum flow rate and washed with bidistilled water to become acid free. The metal ions $(100 \mathrm{ml})$ with $100 \mu \mathrm{g} \mathrm{ml}^{-1}$ at the optimum $\mathrm{pH}$ were passed through the column at the optimum flow rate; the column was washed with $100 \mathrm{ml}$ of bidistilled water to remove any uncomplexed metal ions from the resin bed. The stripping of metal ions from the resin was carried out by $\mathrm{HCl}$. The eluted metal ions were collected in a $100-\mathrm{ml}$ calibrated flask and the concentration was determined.

\section{Results and Discussion}

\section{Characterization of the modified resin}

The DAPCH-Duolite C20 resin was characterized by the nitrogen content (Found 7.6 (Calcd. 9.2\%)) which is absent in Duolite $\mathrm{C} 20$, as well as by the absence of $\mathrm{Cl}^{-}$ions, indicating that the resin is modified with hydrazone by $0.32 \mathrm{~g} \mathrm{~g}^{-1}$. The water content increases from $0.18 \mathrm{~g} \mathrm{~g}^{-1}$ in Duolite C20 to $0.37 \mathrm{~g}$ $\mathrm{g}^{-1}$ in Duolite C20-DAPCH, indicating an increased hydrophilic character of the modified resin which favors faster metal ion sorption and does not depend on the surface area or the pore diameter. ${ }^{34}$ The water content is also supported by the high \% of $\mathrm{H}$ in the modified resin (Found 9.5 (Calcd. 4.6)).

In order to verify the presence of the active functional groups of DAPCH in the modified resin, we compared the IR spectra of Duolite C20, DAPCH and Duolite C20-DAPCH. The IR spectrum of Duolite C20 exhibits bands at 1212, 1173 and 1127 $\mathrm{cm}^{-1}$ attributed to the $\mathrm{SO}_{3}$ stretching, ${ }^{35}$ and the less intense band at $600 \mathrm{~cm}^{-1}$ was assigned to $v(\mathrm{C}-\mathrm{S})$. The broad band at 3450 $\mathrm{cm}^{-1}$ is due to hydrated water. The spectrum of the DAPCH is characterized by strong bands at 3440,3160 and $1700 \mathrm{~cm}^{-1}$ assigned to $v(\mathrm{OH}), v(\mathrm{NH})$ and $v(\mathrm{C}=\mathrm{O})$ vibrations; the less intense bands at 3003, 2953 and 2901 are attributed to the pyridinium group. Upon modification of Duolite C20 with $\mathrm{DAPCH}$, the pyridinium bands are weakened and shifted slightly to lower wave numbers, where the $\mathrm{SO}_{3}{ }^{-}$bands are shifted to lower wave numbers indicating the formation of ionic bonds with the release of $\mathrm{NaCl}$.

The metal coordination on the modified resin was confirmed by the shift of $v(\mathrm{C}=\mathrm{O})$ to lower frequency $\left(15-25 \mathrm{~cm}^{-1}\right)$. The azomethine group is found as a broad band that shifted to a lower wave number by $15 \mathrm{~cm}^{-1}$. This behavior indicates that, the ligand coordinates in the keto form through nitrogen and oxygen donors.

\section{Preliminary investigations}

Batch and column preliminary experiments were carried out to investigate the quantitative sorption of the studied metal ions by Duolite C20 and modified Duolite C20-DAPCH. It was found that Duolite C20 does not show any tendency for the sorption of the studied metal ions. On the other hand, the modified resin is efficient due to the strong interaction between the metal ion and the function groups in the loaded hydrazone via complexation. The analytical variables have been studied through the batch and column techniques.

\section{Batch technique}

Effect of $\mathrm{pH}$. The effect of $\mathrm{pH}$ on the sorption of the studied metal ions has been investigated at $\mathrm{pH} 1-4$. The experiment was elaborated by shaking the solution containing the metal ion with the modified resin of variable acidity for sufficient equilibrium time. Figure 1 shows the maximum sorption efficiency of Duolite C20-DAPCH for Ga(III), In(III) and $\mathrm{Tl}(\mathrm{III})$ ions at $\mathrm{pH} \mathrm{2-3.} \mathrm{For} \mathrm{subsequent} \mathrm{experiments,} \mathrm{the}$ 


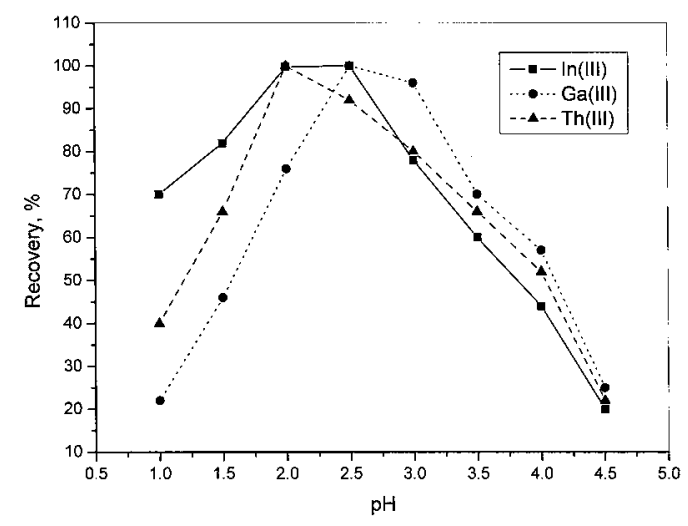

Fig. 1 Effect of $\mathrm{pH}$ on the extraction $\%$ of $\mathrm{Ga}(\mathrm{III}), \mathrm{In}(\mathrm{III})$ and $\mathrm{Tl}(\mathrm{III})$ using $50 \mathrm{mg}$ of the resin; stirring time, $30 \mathrm{~min}$ at $20^{\circ} \mathrm{C}$.

working medium is adjusted at $\mathrm{pH} 2.5$ for $\mathrm{In}(\mathrm{III})$ and $\mathrm{Ga}(\mathrm{III})$ and at 2.0 for $\mathrm{In}(\mathrm{III})$. Acidic $\mathrm{pH}$ is generally preferred in the analysis of real samples to prevent the precipitation of metal hydroxides.

Sorption capacity. The sorption capacity of the modified resin for the studied metal ions was determined by shaking the solution containing excess metal ion with $50 \mathrm{mg}$ of the resin under optimum conditions. The maximum sorption capacity for $\mathrm{Ga}(\mathrm{III}), \mathrm{In}(\mathrm{III})$, and/or $\mathrm{Tl}(\mathrm{III})$ is $0.956,0.815$ and $0.441 \mathrm{mmol}$ $\mathrm{g}^{-1}$, respectively, indicating that the molar ratio of metal ion: DAPCH on resin was about 1:1 for In(III) and Ga(III) and about 1:2 for $\mathrm{Tl}(\mathrm{III})$ (the calculated amount of DAPCH loaded on Duolite C20 is $1.04 \mathrm{mmol} \mathrm{g}^{-1}$ ). The higher capacity of Ga(III) may be due to its lower size.

Amount of resin. The amount of resin is an important parameter that affects the recovery of the metal ions. To show its effect on the quantitative sorption of $\mathrm{Ga}(\mathrm{III}), \mathrm{In}(\mathrm{III})$ and $\mathrm{Tl}(\mathrm{III})$ ions, we used $25-500 \mathrm{mg}$ of the resin. The recovery reaches maximum at $50-200 \mathrm{mg}$. Thus, the minimum amount, $50 \mathrm{mg}$ of the resin has been used for subsequent experiments. At less than $50 \mathrm{mg}$, no quantitative sorption is obtained. On the other hand, amounts over $200 \mathrm{mg}$ prevent the elution of the quantitative sorbed metal ion due to the small volume of eluent. For this reason, the used amount of resin was optimized.

Stirring time. To determine the rate of sorption of metal ion on the modified resin, we conducted batch experiments by shaking the solution containing the ion with $50 \mathrm{mg}$ of the modified resin at room temperature $\left(25^{\circ} \mathrm{C}\right)$. Aliquots of $1 \mathrm{ml}$ solution were taken for analysis at interval times. The concentration of the metal ions in the supernatant solution was determined and the sorbed amount was calculated by mass balance. The sorption half-time $\left(t_{1 / 2}\right)$, defined as the time needed to reach $50 \%$ of the total sorption capacity, was estimated from Fig. 2. It was observed that the sorption of $\mathrm{Ga}(\mathrm{III}), \mathrm{In}(\mathrm{III})$, and $\mathrm{Tl}(\mathrm{III})$ ions with the resin takes times of 25,17 and $30 \mathrm{~min}$, respectively, at $25^{\circ} \mathrm{C}$ to reach equilibrium. However, 10,5 and $10 \mathrm{~min}$ was the time required for $50 \%$ sorption of In (III), Ga(III), and Tl(III), respectively.

Effect of temperature. Temperature is an important variable that affects the equilibrium as well as the sorption of the metal ions. The sorption of $\mathrm{Ga}(\mathrm{III}), \mathrm{In}(\mathrm{III})$ and $\mathrm{Tl}(\mathrm{III})$ ions was investigated over a temperature range of $25-70^{\circ} \mathrm{C}$, which reflects the laboratory ambient conditions. In general, the sorption time decreases with increasing temperature, reaching 18, 12 and 20 min at $70^{\circ} \mathrm{C}$ for $\mathrm{Ga}(\mathrm{III}), \mathrm{In}(\mathrm{III})$ and $\mathrm{Tl}(\mathrm{III})$, respectively. The effect of temperature was taken as a factor in analysis of cold

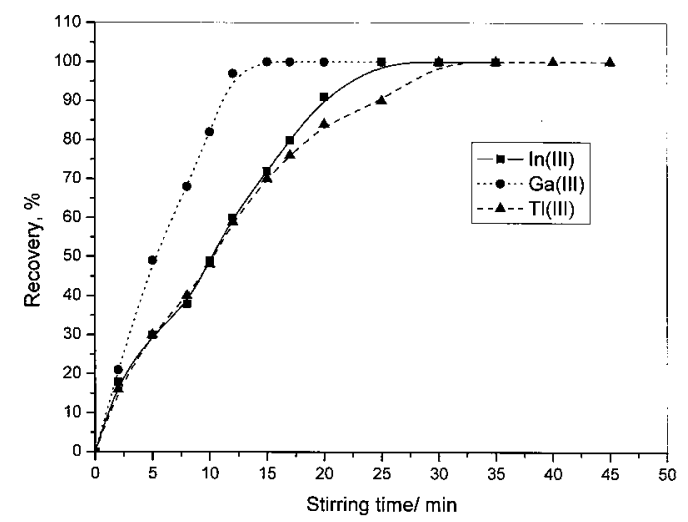

Fig. 2 Effect of stirring time on the extraction of $\mathrm{Ga}$ (III), In(III) and $\mathrm{Tl}(\mathrm{III})$ using $50 \mathrm{mg}$ of the resin at $\mathrm{pH} 2.5$ and $T=20^{\circ} \mathrm{C}$.

and hot samples. All subsequent experiments were carried out at room temperature, $25 \pm 2^{\circ} \mathrm{C}$.

Resin stability and reusability. The modified resin $(50 \mathrm{mg})$ was shaken with $100 \mathrm{ml}$ of $\mathrm{HCl}\left(1-6 \mathrm{~mol} \mathrm{l}^{-1}\right)$ or $1 \mathrm{~mol} \mathrm{l}^{-1}$ of $\mathrm{NaCl}$, $\mathrm{KCl}$ or $\mathrm{NaNO}_{3}$ and/or organic solvents (ethanol, acetone and chloroform) solutions for $24 \mathrm{~h}$. Then the mixtures were filtered and washed with bidistilled water. After air drying, various elemental constituents were investigated. It was found that there was no change in the resin composition, suggesting a stable nature of the modified resin. It was noticed that the hydrazone attached to the resin in the acid media began to dissociate in the alkaline solutions at $\mathrm{pH}>9$ and the dissociation increases with the alkalinity of the solution.

The exchange capacity of $\mathrm{Ga}(\mathrm{III}), \mathrm{In}(\mathrm{III})$, and $\mathrm{Tl}(\mathrm{III})$ on the modified resin was subjected to several sorption and desorption cycles. The resin $\left(50 \mathrm{mg}\right.$ ) was stirred with $100 \mathrm{ml}$ of $25 \mathrm{mg} \mathrm{l}^{-1}$ solution containing $\mathrm{Ga}(\mathrm{III})$, In(III) or $\mathrm{Tl}(\mathrm{III})$ for $1 \mathrm{~h}$ at room temperature. The concentration of the metal ion containing the resin was determined after elution with $5 \mathrm{ml}$ of an appropriate concentration of $\mathrm{HCl}$. Less than $2 \%$ sorption capacity for $\mathrm{In}(\mathrm{III}), \mathrm{Ga}(\mathrm{III})$ or $\mathrm{Tl}(\mathrm{III})$ ions was found, indicating that the modified resin is highly stable and can used several times. The modified resin stored for 6 months under the ambient conditions has the same sorption capacity.

Choice of eluent. An effective eluent for the quantitative stripping of the retained metal ions on the resins must be selected. The metal sorbed can be eluted with acids or complexing agents such as sodium tartrate and EDTA. It was shown that the presence of a complex containing the analyte may cause severe suppression of the analyte signal. So the use of acid solution is analytically preferred. The data obtained in Fig. 3 indicate that $5 \mathrm{ml}$ of $0.5,5.0$ and $2.0 \mathrm{~mol} \mathrm{l}^{-1} \mathrm{HCl}$ afford quantitative elution of $\mathrm{Ga}(\mathrm{III}), \mathrm{In}(\mathrm{III})$ and $\mathrm{Tl}(\mathrm{III})$ ions from the modified resin. Subsequent elution of the metal ions was carried out with $\mathrm{HCl}$ solution, taking advantage of the fact that chloride ion is an acceptable matrix for the spectrophotometric technique under consideration.

Effect of interfering ions. DAPCH reacts with many metal ions due to its rich donor groups; in this form it is unselective. In its loading with Duolite C20 and at the recommended conditions, it became sensitive and selective. The effect of the added interfering agents on the recovery of the metal ions was studied. Nitrate, chloride, acetate, $\mathrm{Na}^{+}, \mathrm{K}^{+}, \mathrm{Mg}^{2+}$ and $\mathrm{Ca}^{2+}$ do not interfere till $200 \mathrm{ppm}$, while $\mathrm{SO}_{4}{ }^{2-}$ (Table 1) gave a surprise, it does not interfere till $1000 \mathrm{ppm}$. However, the complex forming agents such as oxalate, citrate, tartrate, thiourea, 


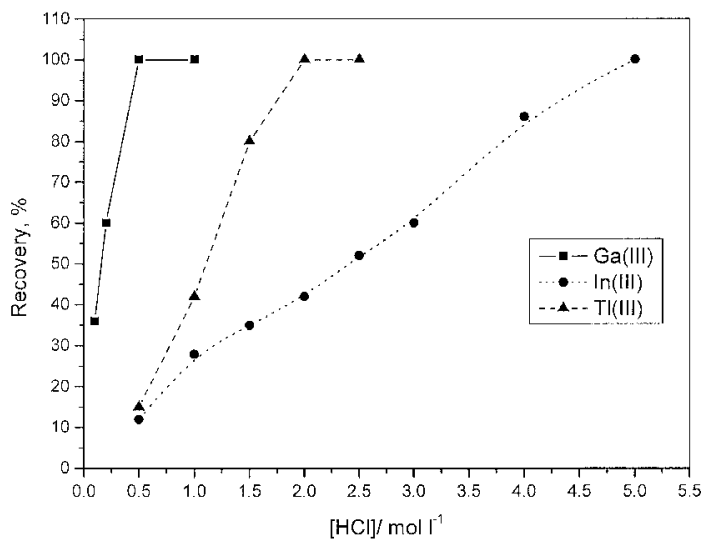

Fig. 3 Effect of $\mathrm{HCl}$ concentration on the recovery of $\mathrm{Ga}(\mathrm{III})$, $\mathrm{In}(\mathrm{III})$ and $\mathrm{Tl}(\mathrm{III})$ using $50 \mathrm{mg}$ of the resin; stirring time, $10 \mathrm{~min}$ at $20^{\circ} \mathrm{C}$.

Table 1 Influence of interfering ions on the recovery of $10 \mu \mathrm{g}$ $\mathrm{ml}^{-1}$ metal ions under investigation using modified resin and shaking for $30 \mathrm{~min}$ at $20^{\circ} \mathrm{C}$

\begin{tabular}{lcccc}
\hline \multirow{2}{*}{$\begin{array}{l}\text { Interfering } \\
\text { ion }\end{array}$} & \multirow{2}{*}{$\begin{array}{c}\text { Concentration/ } \\
\mu \mathrm{g} \mathrm{ml}^{-1}\end{array}$} & \multicolumn{3}{c}{ Recovery, \% } \\
\cline { 3 - 5 } & & $\mathrm{Ga}(\mathrm{III})$ & $\mathrm{In}(\mathrm{III})$ & $\mathrm{Tl}(\mathrm{III})$ \\
\hline $\mathrm{K}^{+}$ & 200 & 96 & 98 & 91 \\
$\mathrm{Mg}^{2+}$ & 200 & 95 & 98 & 92 \\
$\mathrm{Ca}^{2+}$ & 200 & 93 & 96 & 90 \\
$\mathrm{NH}_{4}{ }^{+}$ & 200 & 97 & 98 & 95 \\
Acetate & 200 & 88 & 96 & 78 \\
Oxalate & 200 & 60 & 86 & 58 \\
Tartrate & 200 & 74 & 82 & 64 \\
Citrate & 200 & 70 & 80 & 50 \\
Thiourea & 200 & 71 & 84 & 64 \\
$\mathrm{NO}_{3}{ }^{-}$ & 200 & 94 & 98 & 91 \\
$\mathrm{Cl}^{-}$ & 200 & 98 & 97 & 94 \\
$\mathrm{~F}^{-}$ & 200 & 93 & 96 & 90 \\
$\mathrm{~S}_{2} \mathrm{O}_{3}{ }^{2-}$ & 200 & 66 & 76 & 53 \\
$\mathrm{EDTA}_{\mathrm{SO}_{4}{ }^{2-}}$ & 200 & 32 & 90 & 45 \\
\hline
\end{tabular}

thiosulfate and EDTA exhibited a remarkable suppression of the metal sorption. The surprising phenomenon may find applications in sulfate samples.

\section{Column technique}

Effect of flow rate. The effect of flow rate on the metal sorption was investigated by varying the flow rate from 0.5 to $10 \mathrm{ml}$ $\min ^{-1}$ under the optimum conditions. It was found that the optimum flow rate for the maximum sorption capacity of $\mathrm{Ga}(\mathrm{III}), \mathrm{In}(\mathrm{III})$ and $\mathrm{Tl}(\mathrm{III})$ was 2,5 and $2 \mathrm{ml} \mathrm{min}^{-1}$, respectively. Less than $2 \mathrm{ml} \mathrm{min}^{-1}$ took a long time. However, at flow rates greater than $2 \mathrm{ml} \mathrm{min}^{-1}$, the $\mathrm{Ga}$ (III) and $\mathrm{Tl}(\mathrm{III})$ systems do not reach equilibrium. The faster sorption of In(III) with the modified resin is taken as an indication of its higher reactivity with the resin.

Breakthrough capacity. This was used to evaluate the amount of metal ion sorbed per gram on the modified resin under the operating optimum conditions. ${ }^{36}$ In order for us to obtain a breakthrough capacity, a glass column was packed with $0.5 \mathrm{~g}$ of the modified resin; then $100 \mu \mathrm{g} \mathrm{ml}^{-1}$ of $\mathrm{Ga}(\mathrm{III}), \mathrm{In}(\mathrm{III})$ or $\mathrm{Tl}(\mathrm{III})$ ion solution acidified at the optimum $\mathrm{pH}$ was passed through the

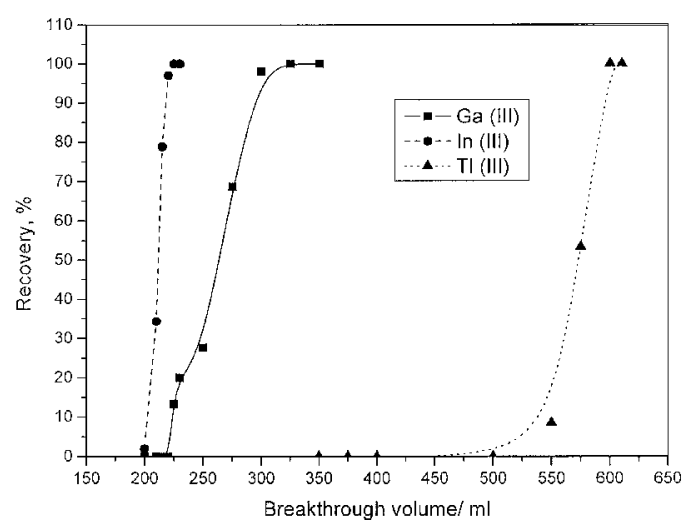

Fig. 4 Breakthrough curve for $\mathrm{Ga}(\mathrm{III}), \mathrm{In}(\mathrm{III})$ and $\mathrm{Tl}(\mathrm{III})$ with a flow rate of $2 \mathrm{ml} \mathrm{min}^{-1}$ at $20^{\circ} \mathrm{C}$.

column with the selected flow rate. The receiving effluent after $5 \mathrm{~min}$ was fractionalized into $5 \mathrm{ml}$ portions and each metal ion was determined. The breakthrough capacity values presented in Fig. 4 indicate that the column is exhausted with $0.932,0.797$ and $0.587 \mathrm{mmol}$ of $\mathrm{Ga}(\mathrm{III}), \mathrm{In}(\mathrm{III})$ and $\mathrm{Tl}(\mathrm{III})$, respectively.

Column reuse. To test the long-term stability of the column containing the modified resin, we created successive sorption and elution cycles by passing the metal ion solution through the column at the optimum flow rate. The sorbed metal ion is then eluted from the resin with different concentrations of $\mathrm{HCl}$. The procedure was carried out several times and the stability of the column was assessed by monitoring the change in the recoveries of the sorbed metal ions. The results of fifty sorption/desorption cycles indicated that the recovery decreased by $2-3 \%$ for $\mathrm{Ga}(\mathrm{III}), \mathrm{In}(\mathrm{III})$ and $\mathrm{Tl}(\mathrm{III})$ ions, which reflect the good stability of the modified resin.

Effect of volume and preconcentration factor. Through the modified resin bed, $0.1-1.51$ aqueous solutions containing 10 $\mu \mathrm{g}$ of $\mathrm{In}(\mathrm{III}), \mathrm{Ga}(\mathrm{III})$ or $\mathrm{Tl}(\mathrm{III})$ ions were passed, each was eluted with $5 \mathrm{ml}$ of the appropriate concentration of $\mathrm{HCl}$ and each concentration was determined. It was found that $\mathrm{Ga}(\mathrm{III})$ and $\mathrm{Tl}(\mathrm{III})$ ions could be removed quantitatively from volumes up to $500 \mathrm{ml}$ and $\mathrm{In}(\mathrm{III})$ up to $750 \mathrm{ml}$; then the recovery decreased remarkably. Therefore, using $5 \mathrm{ml}$ of appropriate concentration of $\mathrm{HCl}$ as eluent, a practical maximum of 100fold preconcentration factor for $\mathrm{Ga}(\mathrm{III})$ and $\mathrm{Tl}(\mathrm{III})$ and 150-fold for In(III) was obtained.

Detection limit of the metal ion. This means the lowest concentration of the metal ion, below which the quantitative sorption by the modified resin is not perceptible. It was investigated for $\mathrm{Ga}(\mathrm{III}), \mathrm{In}(\mathrm{III})$ and $\mathrm{Tl}(\mathrm{III})$ ions by passing $10^{-1}-$ $10^{-3} \mu \mathrm{g} \mathrm{ml}^{-1}$ through the resin bed at a suitable flow rate for each metal ion. The limit of detection (LOD) is 20, 20 and 13 ppb for $\mathrm{Ga}(\mathrm{III}), \mathrm{Tl}(\mathrm{III})$ and $\mathrm{In}(\mathrm{III})$ ions, respectively, showing the high sensitivity of the modified resin in preconcentrating trace analyte.

Applications

Separation of $\mathrm{Ga}(I I I), \operatorname{In}(I I I)$ and $\mathrm{Tl}(\mathrm{III})$ each from synthetic mixtures. In order to separate selectively the studied metal ions from mixtures containing other metal ions, we took an aliquot of aqueous solution $(0.5 \mathrm{l})$ containing $5 \mathrm{mg}$ of the studied metal ion and $50 \mathrm{mg}$ of other cations and followed the recommended procedure (column mode). The results as summarized in Table 2 show that $\mathrm{Ga}(\mathrm{III}), \mathrm{In}(\mathrm{III})$ and $\mathrm{Tl}(\mathrm{III})$ in the mixtures are each 
Table 2 Determination of Ga(III), In(III) and Tl(III) (5 ppm each) from synthetic mixture (100 ppm each) in $100 \mathrm{ml} \mathrm{sample} \mathrm{at} \mathrm{pH} 2.5$ (column mode)

\begin{tabular}{|c|c|c|c|c|c|c|c|c|c|}
\hline \multirow{2}{*}{ Synthesized mixture } & \multicolumn{3}{|c|}{$\mathrm{Ga}(\mathrm{III})$} & \multicolumn{3}{|c|}{$\operatorname{In}(\mathrm{III})$} & \multicolumn{3}{|c|}{$\mathrm{Tl}(\mathrm{III})$} \\
\hline & ppm & $R, \%$ & RSD & ppm & $R, \%$ & RSD & ppm & $R, \%$ & RSD \\
\hline $\mathrm{Hg}(\mathrm{II})+\mathrm{Mn}(\mathrm{II})^{\mathrm{a}}$ & 4.93 & 98.6 & 0.33 & 4.96 & 99.2 & 0.45 & 4.93 & 98.6 & 0.77 \\
\hline $\mathrm{Zn}(\mathrm{II})+\mathrm{Pb}(\mathrm{II})^{\mathrm{a}}$ & 4.95 & 99.0 & 0.56 & 4.98 & 99.6 & 0.21 & 4.94 & 98.8 & 0.80 \\
\hline $\mathrm{Ni}(\mathrm{II})+\mathrm{Cd}(\mathrm{II})^{\mathrm{a}}$ & 4.98 & 99.6 & 0.25 & 4.96 & 99.2 & 0.53 & 4.96 & 99.2 & 0.35 \\
\hline $\mathrm{Co}(\mathrm{II})+\mathrm{Cu}(\mathrm{II})^{\mathrm{a}}$ & 4.96 & 99.2 & 0.60 & 4.97 & 99.4 & 0.22 & 4.90 & 98.0 & 1.45 \\
\hline $\mathrm{Al}(\mathrm{III})+\mathrm{Cr}(\mathrm{III})^{\mathrm{b}}$ & 4.95 & 99.0 & 0.85 & 4.92 & 98.4 & 1.10 & 4.95 & 99.0 & 0.60 \\
\hline $\mathrm{Al}(\mathrm{III})+\mathrm{Fe}(\mathrm{III})^{\mathrm{b}}$ & 4.86 & 97.2 & 2.50 & 4.83 & 96.6 & 3.20 & 4.71 & 94.2 & 4.30 \\
\hline
\end{tabular}

a. At $\mathrm{pH}$ 2.5. b. In the presence of $0.1 \mathrm{~mol} \mathrm{l}^{-1} \mathrm{Na}_{2} \mathrm{SO}_{4}$. RSD: relative standard deviation. Conditions: flow rate, $2 \mathrm{ml} \mathrm{min}^{-1} ; n=5$ at $20^{\circ} \mathrm{C}$.

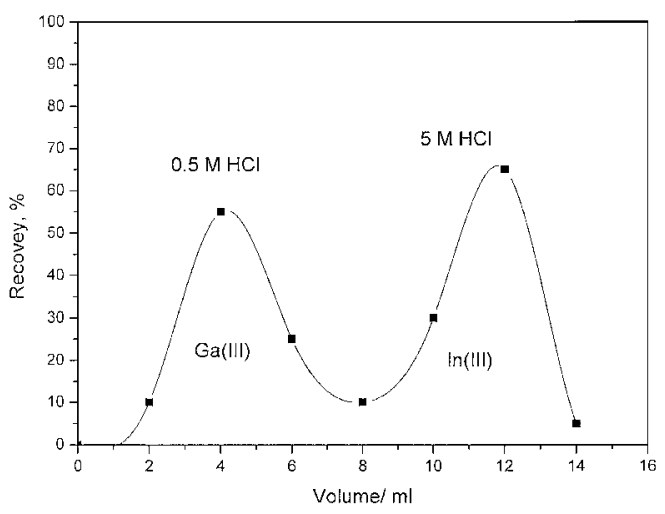

Fig. 5 Effect of eluent concentration on the separation of $\mathrm{Ga}(\mathrm{III})$ from $\operatorname{In}(\mathrm{III})$.

sorbed by the resin, even up to $50 \mathrm{mg}$ of the other interfering cations where no effect on their recovery in the presence of 0.1 mol $1^{-1}$ sodium sulfate is seen under the optimum conditions.

Chromatographic separation of Ga(III) from In(III) or Tl(III). The effect of eluent concentration on the recovery revealed that $\mathrm{Ga}(\mathrm{III})$ is separated from $\mathrm{In}(\mathrm{III})$ selectively. A mixture of $\mathrm{Ga}$ (III) and In(III) (100 $\mu \mathrm{g}$ each) is passed through the column at $\mathrm{pH}$ 2.5. The elution of $\mathrm{Ga}$ (III) is carried out with $8 \mathrm{ml}(2 \mathrm{ml}$ $\times 4)$ of $\mathrm{HCl}\left(0.5 \mathrm{~mol} \mathrm{l}^{-1}\right)$ added with a flow rate of $2 \mathrm{ml} \mathrm{min}^{-1}$. $\mathrm{In}(\mathrm{III})$ is eluted with another $6 \mathrm{ml}(2 \mathrm{ml} \times 3)$ of $5 \mathrm{~mol} \mathrm{l}^{-1} \mathrm{HCl}$ at a flow rate of $2 \mathrm{ml} \mathrm{min}^{-1}$ (Fig. 5).

$\mathrm{Ga}(\mathrm{III})$ is also separated selectively from $\mathrm{Tl}(\mathrm{III})$ by passing a mixture of both $(100 \mu \mathrm{g}$ each) through the column at $\mathrm{pH} 2.5 ; 8$ $\mathrm{ml}(2 \mathrm{ml} \times 4)$ of $0.5 \mathrm{~mol} \mathrm{l}^{-1} \mathrm{HCl}$ is sufficient to elute $\mathrm{Ga}(\mathrm{III})$, where $\mathrm{Tl}(\mathrm{III})$ is retained in the column with another $8 \mathrm{ml}(2 \mathrm{ml}$ $\times 4$ ) of $2 \mathrm{~mol} \mathrm{l}^{-1} \mathrm{HCl}$ (Fig. 6).

\section{Conclusions}

The introduced modified resin (DAPCH-Duolite C20) is found suitable and efficient for trace enrichment of Ga(III), In(III) and $\mathrm{Tl}(\mathrm{III})$. The proposed procedure is simple and fast for sorption and preconcentration of the metal ions without using organic solvents. In comparison with the other modified resins, the main advantages of DAPCH-Duolite C20 resin were: (1) higher preconcentration factor; (2) higher sorption capacity; (3) low matrix effect; (4) good precision; (5) strong stability in acidic medium; (6) quantitative sorption at a very low concentration of $\mathrm{Ga}(\mathrm{III}), \mathrm{In}(\mathrm{III})$ and $\mathrm{Tl}(\mathrm{III})$ in samples having complicated and variable matrices; (7) recycling for 50 cycles, and (8) a short

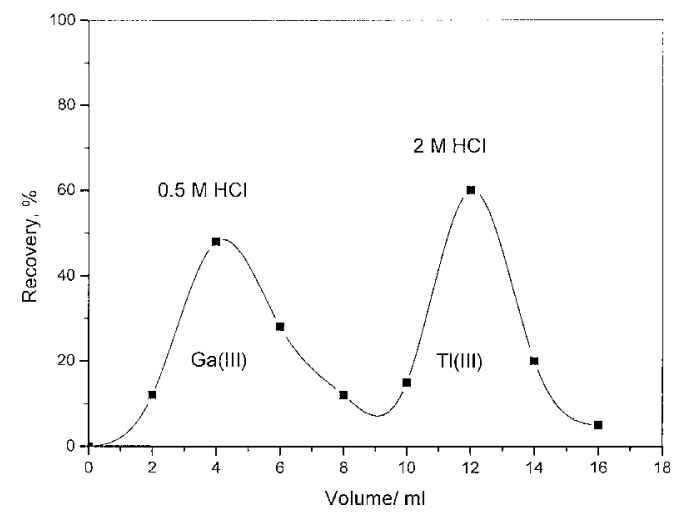

Fig. 6 Effect of eluent concentration on the separation of Ga(III) from Tl(III).

loading time $\left(t_{1 / 2}\right)$. From the economic point of view, the sorption capacity of the modified resin, after its versatile use for 6 months and after being stored under ambient conditions, is practically unchanged.

\section{References}

1. J. C. Bailar, H. J. Emeleus, R. Nytholm, and A. P. Trotman-Dickenson, "Comprehensive Inorganic Chemistry", 1st ed., 1973, Pergamon, London.

2. S. Alegret, "Developments in Solvent Extraction", 1988, Wiley, New York.

3. J. Rydberg, C. Musikas, and G. R. Choppin, "Principles and Practices of Solvent Extraction", 1992, Marcel Dekker, New York.

4. X. Zhang, G. Yin, and Z. Hu, Talanta, 2003, 59, 905.

5. M. Tanaka and H. Akaiwa, "Solvent Extraction Chemistry", 2000, Shokabo, Tokyo.

6. K. Yamamoto and A. Matsumoto, Talanta, 1997, 44, 2145.

7. S. Nishihama, A. Hino, T. Hirai, and I. Komasawa, J. Chem. Eng. Jpn., 1998, 31, 818.

8. S. V. Vartak and V. M. Shinde, Talanta, 1998, 45, 925.

9. J. Jayachandran and P. Dhadke, Hydrometallurgy, 1998, $50,117$.

10. H. Imura, A. Oshiro, and K. Ohashi, Anal. Sci., 1998, 14, 1093.

11. J. Noro, Anal. Sci., 1998, 14, 1099.

12. K. Yamamoto and N. Katoh, Anal. Sci., 1999, 15, 1013.

13. V. K. Puvvada, Hydrometallurgy, 1999, 52, 9.

14. S. Y. Choi and K. Ohashi, Anal. Sci., 2000, 16, 169. 
15. H. Filik and R. Apak, Sep. Sci. Technol., 1994, 29, 2047.

16. K. Ohashi, R. Iwata, S. Mochizuki, H. Imura, K. Hiratani, and H. Sugihara, Talanta, 1996, 43, 1481.

17. Q. Wang, K. Tsunoda, H. Akaiwa, M. Sugiya, and T. Watanabe, Anal. Sci., 1996, 12, 931.

18. Q. T. H. Le, S. Umetani, M. Suzuki, and M. Matsui, J. Chem. Soc. Chem. Commun., 1995, 2271.

19. Q. T. H. Le, S. Umetani, and M. Matsui, J. Chem. Soc. Dalton Trans., 1997, 3835.

20. H. Yamada, Y. Taguchi, and H. Wada, Anal. Sci., 1997, 13, 355.

21. H. Maeda and H. Egawa, J. Appl. Polym. Sci., 1991, 42 737.

22. A. W. Trochimczuk, E. P. Horwitz, and S. D. Alexandratos, Sep. Sci. Technol., 1994, 29, 543.

23. S. K. Sahni and J. Reedijk, Coord. Chem. Rev., 1984, $59,1$.

24. R. A. Beauvais and S. D. Alexandratos, React. Funct. Polym., 1998, 36, 113.

25. R. Horiguchi, I. Nukatsuka, Y. Shimizu, S. Sekikawa, and K. Ohzeki, Bunseki Kagaku, 2002, 51, 675.

26. X. J. Chang, Q. Q. Su, X. J. Wei, and B. T. Wang,
Mikrochim. Acta, 2001, 137, 209.

27. M. Q. Yu, W. Tian, D. W. Sun, W. B. Shen, G. P. Wang, and N. Xu, Anal. Chim. Acta, 2001, 428, 209.

28. J. S. Liu, H. Chen, X. Y. Chen, Z. L. Guo, Y. C. Hu, C. P. Liu, and Y. Z. Sun, Hydrometallurgy, 2006, 82, 137.

29. S. D. Alexandratos, A. W. Trochimczuk, E. P. Horwitz, and R. C. Gatrone, J. Appl. Polym. Sci., 1996, 61, 273.

30. A. W. Trochimczuk and J. Jezierska, Polymer, 1997, 38, 2431.

31. A. W. Trochimczuk, Eur. Polym. J., 1998, 34, 1657.

32. A. W. Trochimczuk, React. Funct. Polym., 2000, 44, 9.

33. Z. Marczenko, "Separation and Spectrophotometric Determination of Elements", 2nd ed., 1986, Ellis Horwood Ltd., New York.

34. N. Das and J. Das, Ind. J. Chem., 1989, 28, 150.

35. K. Nakamoto, "Infrared Spectra of Inorganic and Coordination Compounds", 1970, Wiley Interscience, New York.

36. M. Pesavento, R. Biesuz, G. Alberti, and M. Sturini, J. Sep. Sci., 2003, 26, 381. 